Asian J. Med. Biol. Res. 2020, 6 (3), 594-598; doi: 10.3329/ajmbr.v6i3.49813

\author{
Asian Journal of \\ Medical and Biological Research \\ ISSN 2411-4472 (Print) 2412-5571 (Online) \\ www.ebupress.com/journal/ajmbr
}

\title{
Article \\ Postnatal development and egg morphometry of different breeds of pigeon available at northern Barind tract in Bangladesh
}

\author{
Md. Najmul Hassan Parvez ${ }^{1}$, Md. Reazul Islam², Md. Jalal Uddin Sarder² and Md. Royhan Gofur ${ }^{2 *}$ \\ ${ }^{1}$ Dept. of Anatomy and Histology, Hajee Mohammad Danesh Science and Technology University, Dinajpur, \\ Bangladesh \\ ${ }^{2}$ Department of Veterinary and Animal Sciences, University of Rajshahi, Rajshahi-6205, Bangladesh
}

${ }^{*}$ Corresponding author: Dr. Md. Royhan Gofur, Department of Veterinary and Animal Sciences, University of Rajshahi, Rajshahi-6205, Bangladesh. E-mail: royhangm@gmail.com

Received: 07 September 2020/Accepted: 24 September 2020/ Published: 30 September 2020

\begin{abstract}
Pigeon farming, like chicken and duck farming, is getting popularity nowadays in Bangladesh. The present study was conducted on the postnatal development and morphometry of egg of different breeds of pigeon available at northern Barind tract of Bangladesh. The study was conducted at thirty selected pigeon farms of three districts (Rajshahi, Natore and Pabna) of northern Barind tract of Bangladesh. The postnatal development (weight gain of squabs) of five groups (D0, D7, D14, D21, D28; D=day), and morphometry of eggs (egg weight, egg width (short axis), and length (long axis)) of breeds of pigeon $(\mathrm{n}=20$, each breed) available at northern Barind tract in Bangladesh were collected and analyses with Duncan's Multiple Range test (DMRT). Considerable differences in the postnatal weight gain and egg morphometry were found among breeds of pigeon. The mature body weight of Giribaz, Kormona, Nun and Owl breeds of pigeon were below 300 gm; Satinette, Mookee, Suachandan, Lakkha, Jacobin, Bokhara, Shirajee, Homer and Pouter were 300-500 gm, and King and Strasser were below $800 \mathrm{gm}$. The postnatal weight of an age group was significantly different $(\mathrm{p}<0.05)$ from other age groups of all studied breeds. The highest egg length was $4.37 \pm 0.02 \mathrm{~cm}$ in Strasser, and the lowest was $3.68 \pm 0.01 \mathrm{~cm}$ in Giribaz pigeon. The highest egg width was $3.24 \pm 0.19 \mathrm{~cm}$ in Mookee, and the lowest was $2.73 \pm 0.02 \mathrm{~cm}$ in Giribug pigeon. The highest egg weight was $21.20 \pm 0.49 \mathrm{gm}$ in Strasser, and the lowest was $14.00 \pm 0.23 \mathrm{gm}$ in Owl pigeon. Moreover, a relationship between the body weight and egg length, width and weight of pigeons was observed in pigeons of all studied breeds.
\end{abstract}

Keywords: barind tract; pigeon; breed; egg morphometry; postnatal weight gain

\section{Introduction}

Bangladesh has a long historical record of raising poultry under backyard system (Alam et al., 2014). The weather and vast areas of crop field along with housing premises of Bangladesh are suitable for pigeon farming (Asaduzzaman et al., 2009), and thus pigeon is getting popularity as domestic bird (Gofur, 2020). Small-scale family poultry farming involving semi-scavenging flocks of mostly indigenous breed poultry in rural regions of many developing countries contributes in a very meaningful way towards the social and financial needs of rural families (Pym and Alders, 2012). Mankind has practiced pigeon keeping for about 10,000 years in almost every part of the world (Levi, 1977). The pigeon is also very important to all sorts of people from religious aspect. Pigeon breeding is a popular hobby worldwide, and over 350 different breeds are currently recognized (Shapiro and Domyan, 2013). The hobbyist reared pigeon as pet animal, as performing bird, i.e., flat race and fly high that called with kentongan at East Java. Some of them used the pigeon as food like chicken, duck and quail (Darwati et al., 2010). Pigeon eggs are known as "animal ginseng" is rich in protein.

Postnatal development is often measured by postnatal body weight. Alternately, the body weight of an animal is sometimes considered an indicator of its age (McCutcheon and Marinelli, 2009). Growth traits enclosed with suitable environment can achieve maximal performance. Growth data is needed to support 
potential study of the pigeon as meat producer. Pigeons are widely used as experimental models in biomedical research and have also been raised for egg and meat production (Beena, 2019; Bradley et al., 2020). Commercial squab (young pigeon) production has existed in North America since the early 1900s (Stanhope, 1978). Although meat from squabs is produced commercially, information regarding postnatal development and slaughtering time is lacking (Mariam, 2007). There is no clear information regarding the postnatal development (weight gain) and morphometry of egg of different breeds of pigeon. Considering the above, the present study was conducted to reveal the postnatal development and morphometry of egg of different breeds of pigeon available at northern Barind tract in Bangladesh.

\section{Materials and Methods}

The experiment was conducted at the Department of Veterinary and Animal Sciences, Faculty of Agriculture, University of Rajshahi, Rajshahi from June 2018 to June 2019. Thirty selected pigeon farms of three districts (Rajshahi, Natore and Pabna) of Rajshahi division of Bangldesh have been visited and the different breeds of pigeons were recorded. The pigeons $(n=20$, each breed) were reared in scavenging condition and nests were used as a night shelter for protection against predator. Each pair of pigeon was kept in nest separately. The size of each nest was $32 \mathrm{~cm} \times 60 \mathrm{~cm} \times 22 \mathrm{~cm}$. Nest was made strong with iron and was placed at a reasonable height using strong support. The pigeons were offered high quality diets and water ad libitum with high and low protein level. The nests were cleaned periodically for maintaining good body condition of bird. The pigeons were treated with vaccine and deworming. Body weights were measured with an electronic balance in the morning before the birds were fed. Egg width (short axis), and length (long axis) were measured with slide calipers (Figure 1a). Weights of eggs and squabs of five groups (D0, D7, D14, D21, D28; D=day) were measured with an electronic balance (Figure 1b-f). Different record sheets with full details of each parameter were maintained.

Statistical analysis was done the reveal the significant differences of the parameters among the breeds, and different age groups of pigeons. Data was presented as Mean \pm SE. The Duncan's Multiple Range test (DMRT) was performed to observe significant differences between the parameters. All analysis was performed using SPSS software version 20. $\mathrm{p}<0.05$ was considered as significant.
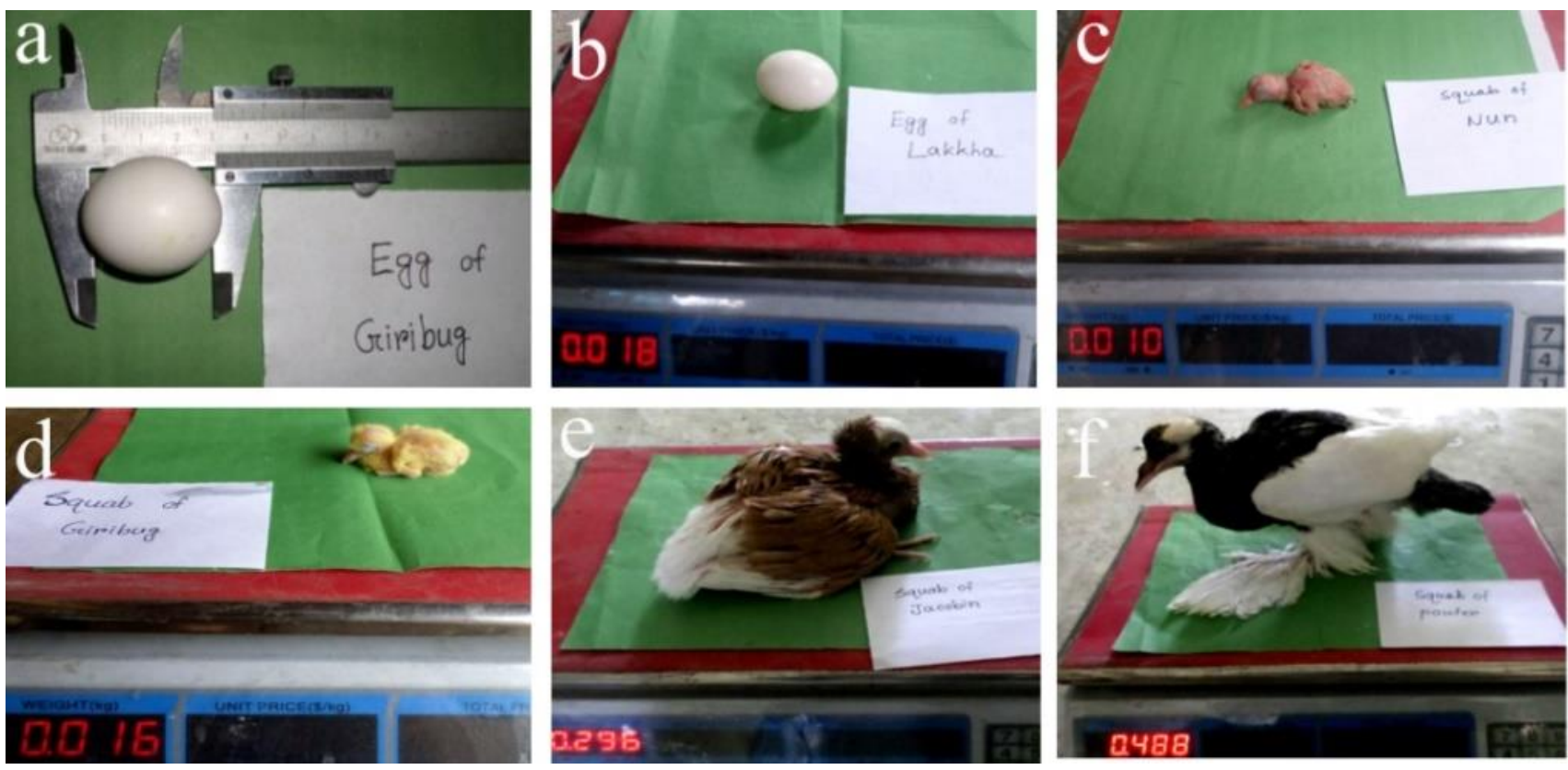

Figure 1. Morphometric measurement of pigeon egg and squab. a, length of egg; b, weight of egg; c, weight of D0 squab (Nun); d, weight of D0 squab (Giribug); e, weight of D28 squab (Jacobin); f, weight of D28 squab (Pouter).

\section{Results and Discussion}

The postnatal development and production traits grown by humans are in many ways different from that of birds in the natural habitats where food availability is seasonal, food scarcity appears to be more frequent and competition is the deciding force for the survival of the birds. Even in the domestic systems of birds keeping, 
there have been considerable variations in the productive and postnatal developmental traits of the birds mainly because of nutritional status of the diet and genetic race of the birds (Chudasama, 2017). In this context, productive performance (egg morphometry) and postnatal development of pigeons varies greatly depending on the breed (Shapiro and Domyan, 2013). Considerable differences in the egg morphometry and postnatal weight gain were found among breeds of pigeon available in northern part of Bangladesh.

The postnatal development (weight gain) of pigeon varies according to the breed, nutrition and management. In the present research work, the mature body weight of Giribaz, Kormona, Nun and Owl breeds of pigeon were below 300 gm; Satinette, Mookee, Suachandan, Lakkha, Jacobin, Bokhara, Shirajee, Homer and Pouter were $300-500 \mathrm{gm}$, and King and Strasser were below $800 \mathrm{gm}$. At day 0 the highest squab weight was found $153.20 \pm 7.53 \mathrm{gm}$ in Strasser and the lowest squab weight was found $18.60 \pm 0.75 \mathrm{gm}$ in Giribug (Table 1). But Darwati et al. (2010) reported that mean body weight of local pigeon on Day old was $14.02 \pm 1.20$ gm which was nearer to the body weight of Giribaz in this research. At day 7 the highest squab weight was found 238.80 \pm 4.13 $\mathrm{gm}$ in Srasser and the lowest squab weight was found $71.60 \pm 4.53 \mathrm{gm}$ in Lakkha. At day 14 the highest squab weight was found $439.20 \pm 12.13 \mathrm{gm}$ in Strasser and the lowest squab weight was found $132.40 \pm 12.07 \mathrm{gm}$ in Lakkha. But Bhowmik (2014) reported that at day 15 the body weight of Jalali pigeon was found 225.53 \pm 3.89

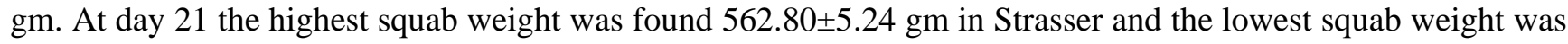
found $206.00 \pm 1.14 \mathrm{gm}$ in Giribug pigeon. But Islam (2010) reported that at day 20 the body weight of Jalali pigeon was $217.10 \mathrm{gm}$ and in case of Giribug pigeon was found $214.00 \mathrm{gm}$. At day 28 the highest squab weight

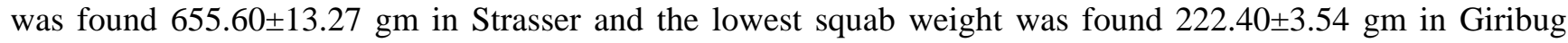
pigeon (Table 2). But Bhowmik (2014) reported that at day 30 the body weight of Jalali pigeon was found $275.59 \pm 1.48$ gm where as Darwati et al. (2010) reported that mean body weight of local pigeon on Day 28 was $290.40 \pm 27.98 \mathrm{gm}$. Azad (2009) also reported in case of Gola breed, male pigeon body weight was $304.10 \mathrm{gm}$ and female pigeon body weight was $257.50 \mathrm{gm}$. Moreover, postnatal weight of an age group was significantly different $(\mathrm{p}<0.05)$ from other age groups of all studied breeds (Table 1). Majewska and Drenikowski (2016) observed the body weight daily gains were 8.83 to $12.61 \mathrm{~g}$ between day 7 and day 14 of rearing, and next decreased to reach 0.47 to $1.77 \mathrm{~g}$ between days 21 and 28. Zielezinski and Pawlina (2011) found a similar pattern. Pawlina and Borys (2009) studied a meat pigeon breed (Wrocław meat) and noticed the drop in daily gains on the end of 4 weeks of age that indicates the maturity of pigeon. The age 4 weeks (D28) is therefore the optimum when meat pigeons should be slaughtered, as their further farming would be economically inefficient.

The size of egg is an important factor of hatchability indices and chick body weight on hatching, which was proved by Ibrahim and Sani (2010). The highest egg length in the present study was found $4.37 \pm 0.02 \mathrm{~cm}$ in Strasser and the lowest egg length was found $3.68 \pm 0.01 \mathrm{~cm}$ in Giribaz pigeon that was similar with the findings of Saxena (2008) but Bhowmik (2014) reported $3.75 \pm 0.06 \mathrm{~cm}$ in case of Jalali pigeon. The highest egg width was found $3.24 \pm 0.19 \mathrm{~cm}$ in Mookee and the lowest egg width was found $2.73 \pm 0.02 \mathrm{~cm}$ in Giribug pigeon that was more or less similar with the result of Bhowmik (2014), who found $2.81 \pm 0.05 \mathrm{~cm}$ in case of Jalali pigeon and also with the findings of Saxena et al. (2008) who reported $2.85 \mathrm{~cm}$. The highest egg weight was found 21.20 $\pm 0.49 \mathrm{gm}$ in Strasser, but Bhowmik (2014) reported 16.18 $\pm 0.08 \mathrm{gm}$ in case of Jalali pigeon, and Robinson (2005) noticed the mean egg weight of domestic pigeon was $18.9 \mathrm{gm}$, and Sales and Janssens (2003) reported the mean egg weight of domestic pigeon was $21.4 \mathrm{gm}$ which was similar with the present study. The lowest egg weight was found $14.00 \pm 0.23 \mathrm{gm}$ in Owl pigeon that was similar with Ibrahim and Sani (2010), who reported that mean egg weight of street pigeons (Columba livia) was 14.46 $\pm 0.11 \mathrm{gm}$ but Abdel-Azeem et al. (2007) and Darwati et al. (2010) reported that egg weight ranged from 13.78 to $17.38 \mathrm{gm}$, and 10.7 to $23.3 \mathrm{gm}$, respectively in pigeon which are in agreement with the results of present study. The variation of pigeon egg weight in different studies may be mainly due to weight variation of adult pigeon of different breeds that is clearly observed in the present study (Table 2). The adult pigeons of weight less than $300 \mathrm{gm}$ laid eggs weighing 14.00 $-15.20 \mathrm{gm}$, pigeons of weight $300-500 \mathrm{gm}$ laid eggs weighing $14.40-20.80 \mathrm{gm}$, and pigeons of weight $501-$ $800 \mathrm{gm}$ laid eggs weighing $21.05-21.20 \mathrm{gm}$. Such relation was also observed between the body weight and egg length and width (Table 2). Robertson (1988) reported a relationship between the body weight and egg weight of pigeons. 
Table 1. Weight of pigeon (squab) of different breeds at different postnatal age $(n=20)$.

\begin{tabular}{|c|c|c|c|c|c|c|}
\hline \multirow{2}{*}{$\begin{array}{l}\text { BW } \\
\text { (gm) }\end{array}$} & \multirow[b]{2}{*}{ Breed } & \multicolumn{5}{|c|}{ Squab weight (gm) } \\
\hline & & D0 & D7 & D14 & D21 & D28 \\
\hline \multirow{4}{*}{$<300$} & Giribaz & $18.60 \pm 0.75^{\mathrm{a}}$ & $75.60 \pm 10.48^{\mathrm{b}}$ & $145.60 \pm 14.13^{\mathrm{c}}$ & $206.00 \pm 1.14^{\mathrm{d}}$ & $222.40 \pm 3.54^{\mathrm{e}}$ \\
\hline & Kormona & $24.00 \pm 1.41^{\mathrm{a}}$ & $74.00 \pm 1.41^{\mathrm{b}}$ & $152.00 \pm 12.36^{\mathrm{c}}$ & $210.00 \pm 3.03^{\mathrm{d}}$ & $247.00 \pm 3.23^{\mathrm{e}}$ \\
\hline & Nun & $24.80 \pm 1.02^{\mathrm{a}}$ & $83.20 \pm 4.27^{\mathrm{b}}$ & $183.20 \pm 4.63^{\mathrm{c}}$ & $270.80 \pm 3.32^{\mathrm{d}}$ & $278.00 \pm 2.83^{\mathrm{e}}$ \\
\hline & Owl & $24.00 \pm 0.71^{\mathrm{a}}$ & $131.20 \pm 8.69^{\mathrm{b}}$ & $230.80 \pm 3.44^{c}$ & $2.68 .20 \pm 2.54^{\mathrm{d}}$ & $290.00 \pm 2.54^{\mathrm{e}}$ \\
\hline \multirow{9}{*}{$\begin{array}{l}300- \\
500\end{array}$} & Satinette & $29.20 \pm 1.02^{\mathrm{a}}$ & $105.60 \pm 1.72^{\mathrm{b}}$ & $212.00 \pm 1.41^{\mathrm{c}}$ & $276.00 \pm 2.28^{\mathrm{d}}$ & $308.80 \pm 3.26^{\mathrm{e}}$ \\
\hline & Mookee & $30.00 \pm 1.41^{\mathrm{a}}$ & $116.80 \pm 4.34^{\mathrm{b}}$ & $216.00 \pm 4.34^{c}$ & $280.80 \pm 4.27^{\mathrm{d}}$ & $312.40 \pm 4.71^{\mathrm{e}}$ \\
\hline & Suachandan & $30.80 \pm 1.02^{\mathrm{a}}$ & $119.60 \pm 5.50^{b}$ & $218.80 \pm 3.26^{\mathrm{c}}$ & $277.60 \pm 2.32^{d}$ & $316.00 \pm 1.41^{\mathrm{e}}$ \\
\hline & Lakkha & $29.80 \pm 1.66^{\mathrm{a}}$ & $71.60 \pm 4.53^{\mathrm{b}}$ & $132.40 \pm 12.07^{\mathrm{c}}$ & $230.00 \pm 1.41^{\mathrm{d}}$ & $330.00 \pm 1.41^{\mathrm{e}}$ \\
\hline & Jacobin & $31.20 \pm 2.42^{\mathrm{a}}$ & $110.40 \pm 7.73^{\mathrm{b}}$ & $224.40 \pm 4.17^{\mathrm{c}}$ & $262.80 \pm 4.63^{\mathrm{d}}$ & $332.00 \pm 7.32^{\mathrm{e}}$ \\
\hline & Bokhara & $51.60 \pm 2.14^{\mathrm{a}}$ & $223.20 \pm 3.61^{\mathrm{b}}$ & $261.60 \pm 3.54^{c}$ & $283.20 \pm 2.42^{\mathrm{d}}$ & $336.00 \pm 9.27^{\mathrm{e}}$ \\
\hline & Shirajee & $52.00 \pm 1.41^{\mathrm{a}}$ & $224.00 \pm 1.41^{\mathrm{b}}$ & $262.00 \pm 1.41^{\mathrm{c}}$ & $370.80 \pm 1.02^{\mathrm{d}}$ & $435.20 \pm 1.86^{\mathrm{e}}$ \\
\hline & Homer & $54.00 \pm 2.00^{\mathrm{a}}$ & $228.00 \pm 3.03^{b}$ & $262.40 \pm 6.52^{\mathrm{c}}$ & $390.00 \pm 3.63^{\mathrm{d}}$ & $438.80 \pm 3.56^{\mathrm{e}}$ \\
\hline & Pouter & $56.40 \pm 2.14^{\mathrm{a}}$ & $231.20 \pm 3.14^{\mathrm{b}}$ & $395.60 \pm 1.72^{c}$ & $446.00 \pm 3.58^{\mathrm{d}}$ & $488.00 \pm 2.45^{\mathrm{e}}$ \\
\hline \multirow{2}{*}{$\begin{array}{l}501- \\
800\end{array}$} & King & $132.40 \pm 2.79^{\mathrm{a}}$ & $236.00 \pm 4.05^{\mathrm{b}}$ & $433.20 \pm 8.09^{\mathrm{c}}$ & $551.60 \pm 6.68^{\mathrm{d}}$ & $645.00 \pm 10.60^{\mathrm{e}}$ \\
\hline & Strasser & $153.20 \pm 7.53^{\mathrm{a}}$ & $238.80 \pm 4.13^{\mathrm{b}}$ & $439.20 \pm 12 . \pm 13^{\mathrm{c}}$ & $562.80 \pm 5.24^{\mathrm{d}}$ & $655.60 \pm 13.27^{\mathrm{e}}$ \\
\hline
\end{tabular}

$\mathrm{BW}$, body weight; D, day; ${ }^{\mathrm{a}, \mathrm{b}, \mathrm{c}, \mathrm{d}, \mathrm{e}}$ Statistically significant $(\mathrm{p}<0.05)$ among age groups of squabs

Table 2. Morphometry of egg of different breeds of pigeon $(n=20)$.

\begin{tabular}{|l|l|l|l|l|}
\hline Body weight (gm) & Breed & Egg length (cm) & Egg width (cm) & Egg weight (gm) \\
\hline \multirow{5}{*}{$<300$} & Giribug & $3.68 \pm 0.03$ & $2.73 \pm 0.02$ & $14.80 \pm 0.75$ \\
\cline { 2 - 5 } & Kormona & $3.70 \pm 0.02$ & $2.75 \pm 0.02$ & $15.20 \pm 0.49$ \\
\cline { 2 - 5 } & Nun & $3.87 \pm 0.04$ & $2.78 \pm 0.03$ & $15.20 \pm 0.49$ \\
\cline { 2 - 5 } & Owl & $3.71 \pm 0.07$ & $2.77 \pm 0.03$ & $14.00 \pm 0.23$ \\
\hline & Satinette & $3.79 \pm 0.04$ & $2.76 \pm 0.06$ & $14.40 \pm 0.75$ \\
\cline { 2 - 5 } & Mookee & $3.81 \pm 0.04$ & $3.24 \pm 0.19$ & $14.80 \pm 0.49$ \\
\cline { 2 - 5 } $300-500$ & Suachandan & $3.69 \pm 0.04$ & $2.80 \pm 0.03$ & $15.20 \pm \pm .49$ \\
\cline { 2 - 5 } & Lakkha & $3.98 \pm 0.07$ & $3.06 \pm 0.02$ & $16.80 \pm 0.49$ \\
\cline { 2 - 5 } & Jacobin & $3.96 \pm 0.06$ & $2.94 \pm 0.04$ & $16.80 \pm 0.49$ \\
\cline { 2 - 5 } & Bokhara & $4.05 \pm 0.06$ & $3.00 \pm 0.02$ & $19.20 \pm 2.14$ \\
\cline { 2 - 5 } & Shirajee & $4.14 \pm 0.04$ & $3.13 \pm 0.05$ & $20.00 \pm 0.63$ \\
\cline { 2 - 4 } & Homer & $4.06 \pm 0.08$ & $3.07 \pm 0.03$ & $19.20 \pm 0.49$ \\
\cline { 2 - 4 } & Pouter & $4.32 \pm 0.07$ & $3.13 \pm 0.05$ & $20.80 \pm 0.41$ \\
\hline \multirow{2}{*}{$501-800$} & King & $4.36 \pm 0.02$ & $3.13 \pm 0.08$ & $21.05 \pm 0.53$ \\
\cline { 2 - 4 } & Strasser & $4.37 \pm 0.02$ & $21.20 \pm 0.47$ \\
\hline
\end{tabular}

\section{Conclusions}

It is possible to improve the breeds of pigeon through selection and other relevant breeding strategies, thereby increasing the productivity of the birds. Considerable differences in the postnatal weight gain and egg morphometry were found among breeds of pigeon. The age around 4 weeks is the optimum when meat pigeons should be slaughtered. There is a relationship between the body weight and egg length, width and weight of pigeons of all studied breeds.

\section{Acknowledgements}

This work was financially supported by the Krishi Gobeshona Foundation (KGF), Bangladesh.

\section{Conflict of interest}

None to declare.

\section{References}

Abdel-Azeem FA, AE Abdel-Rafea and EA Abdullah, 2007. Abdullah. Studies on the effect of different dietary metabolizable energy levels on some performance of local baladi pigeons. Egypt Poult. Sci., 26: 595-611.

Alam MA, MS Ali, NG Das and MM Rahman, 2014. Present status of rearing backyard poultry in selected areas of Mymensingh district. Bang. J. Anim. Sci., 43: 30-37. 
Asaduzzaman M, M Mahiuddin, MAR Howlider, M Hossain and T Yeasmin, 2009. Pigeon farming in Gouripur upazilla of Mymensingh district. Bang. J. Anim. Sci., 38: 142-150.

Azad MAK, 2009. Nutrient availability and body composition of semi-scavenging gola pigeon and meat yield of their squab. MSc, Dept. of Poult. Sci., Bang. Agril. Univ., Mymensingh, Bangladesh.

Beena V, 2019. Applications of livestock in biomedical research. J. Dairy Vet. Anim. Res., 8: 107-109.

Bhowmik N, MM Mia and MA Rahman, 2014. Morphometric measurements, productive and reproductive performance of Jalali pigeon. Int. J. Dev. Res., 4: 908-911.

Bradley A, N Mennie, PA Bibby and Cassaday HJ, 2020. Some animals are more equal than others: Validation of a new scale to measure how attitudes to animals depend on species and human purpose of use. PLoS ONE, 15: $\mathrm{e} 0227948$.

Chudasama P, 2017. Ecological and behavioural study of Common Myna (Acridotheres tristis), Bank Myna (Acridotheres ginginianus) and Brahminy Myna (Sturnia pagodarum) in the urban area of Bhavnagar, Gujarat. PhD Thesis, Maharaja Krishnakumarsinhji Bhavnagar Univ., India.

Darwati S, H Martojo, C Sumantri, DTH Sihombing and A Mardiastuti, 2010. Productivity, repeatability of productive and reproductive traits of local pigeon. J. Indonesian Trop. Anim. Agric., 35: 268-274.

Gofur MR, 2020. Textbook of Avian Anatomy. $1^{\text {st }}$ edn. Uttoran Offset Printing Press, Rajshahi, Bangladesh.

Ibrahim T and Y Sani, 2010. Relationship between egg weight and hatch weight in pigeons (Columba livia). Int. J. Poult. Sci., 9: 599-601.

Islam MR, 2010. Pigeon farming and meat yield of some genetic groups in Mymensingh district. MSc, Dept. of Poult. Sci., Bang. Agril. Univ., Mymensingh, Bangladesh.

Levi W, 1977. The Pigeon. Levi Publishing Company, Inc. USA.

Majewska D and T Drenikowski, 2016. Analysis of reproduction and growth in fancy pigeons. Acta Sci. Pol. Zootechnica, 15: 41-52.

Mariam SA, 2007. Study on management, behavory, physiology and meat characteristics of pigeons in Khartoum State. PhD Thesis, Khartoum Univ., Khartoum, Sudan.

McCutcheon JE and M Marinelli, 2009. Age matters. Eur. J. Neurosci., 29: 997-1014.

Pawlina E and K Borys, 2009. Growth of Wrocław meat breed pigeons in relation to the number of birds in the nest. Rocz. Nauk. PTZ, 5: 44-49.

Pym RAE and RG Alders, 2012. Introduction to village and backyard poultry production. In: Alternative systems for poultry: health, welfare and productivity. Sandilands V and P Hocking, (eds). Australia.

Robertson HA, 1988. Relationships between body weight, egg weight and clutch size in pigeons and doves (Aves: Columbiformes). J. Zool., Lond., 215: 217-229.

Robinson RA, 2005. Bird facts: Profiles of birds occurring in Britain and Ireland. BTO Research Report, Thatord: BTO. http://www.bto.org/bird facts.

Sales J and GPJ Janssens, 2003. Relationship between egg weight and hatch weight in pigeons (Columba livia).World's Poult. Sci., 59: 221-232.

Saxena VL, E Pandey, S Agarwal and AK Saxena, 2008. Execution of breeding and nidification behaviour in pigeon (Columba livia) and dove (Streptopelia chinensis). Asian J. Expt. Sci., 22: 405-410.

Shapiro MD and ET Domyan, 2013. Domestic pigeons. Curr. Biol., 23: R302-R303.

Stanhope B, 1978. The species our ancestors forgot (production possibilities of Japanese quail, squab pigeons, guinea fowl and pheasants, Victoria). J. Agric. Victoria (Australia), 76: 250-251.

Zielezinski M and E Pawlina, 2011. Analiza wzrostu goł ebi ró znych ras [Growth analysis of various pigeon breeds]. Rocz. Nauk. PTZ, 7: 45-51. 